\title{
4 Purpose and Form
}

\author{
On the Translation of Classical Chinese Poetry
}

Wilt L. Idema

\begin{abstract}
This essay contains reflections on issues of purpose and literary form in poetry translation, against the background of translation traditions that change over time. Circling out from a poem by Tang-dynasty poet Han Shan, the author draws on examples from Dutch and English to address issues that bear relevance to classical Chinese poetry's translation into any language, and indeed to the art and the craft and the trade of poetry translation at large.
\end{abstract}

Keywords: Chinese poetry, translation, audience, rhyme, meter, parallelism

There was very little in my background when I grew up in the Dutch countryside to predispose me to the study of Chinese Languages and Cultures, which I chose as my major when I entered Leiden University in the fall of $1963 .{ }^{1}$ Also during my years of study at Leiden, and later in Sapporo, Kyoto, and Hong Kong, there were few indications that suggested that I would end up spending a large part of my adult life reading and translating classical Chinese poetry, first into Dutch, but later also into English. During these early years of my career my interest wavered between contemporary rural sociology and late imperial vernacular literature. My first job at Leiden University was as a researcher at the Documentation Center for Contemporary China, a newly founded section of the well-known Sinological Institute, where I was to follow social developments in the inaccessible People's Republic of China of the Cultural Revolution years,

1 This article is an extended version of a paper presented at the Symposium on Chinese Studies 2018 in Beijing (July 23-24).

Van Crevel, Maghiel and Lucas Klein (eds.), Chinese Poetry and Translation: Rights and Wrongs. Amsterdam: Amsterdam University Press, 2019 DOI: $10.5117 / 9789462989948 \_C H O 4$ 
and my earliest publications are devoted to the educational reforms of the 1960 s and early 1970s. I left the contemporary China field abruptly when Dirk Jonker, the Department's teacher of classical Chinese (文言文) and Chinese literature, suddenly died in the weekend before the start of the 1973 spring term: when I got to work that Monday morning, I was asked to take over his classes from that very day, and that was the end of my career as a China watcher.

Throughout my years in contemporary China studies I had always continued to read traditional Chinese vernacular fiction in large quantities. I liked these sprawling narratives of backstage political intrigues and private bedchamber adventures, so different from the official image of Chinese society projected by the authorities to their own subjects or the outside world, in the past or the present. Some of my first attempts at translation concerned the vernacular short stories (話本) that had been collected and printed by Feng Menglong 馮夢龍 in the 1620s. While these stories are mostly written in prose, they also include occasional couplets, poems, and lyrics. When rendering these texts into Dutch, I wanted to stress the alternation between prose and poetry in its various forms, and so I used meter and rhyme in the poetry passages. With due modesty, I dare say I have a certain talent for rhyming in my native Dutch. I also tried to prepare myself even better for my self-appointed task by reading large quantities of Dutch rhymed verse from the nineteenth century, when Dutch poets all used rhyme as a matter of course. I even became something of an expert in the field, publishing two anthologies of nineteenth-century Dutch poetry in cooperation with Anton Korteweg, a good friend who is a practicing poet and served as the director of the Dutch Museum of Literature. But neither my native talent in versifying nor my assiduous reading of rhymed poetry proved much use. Like many translators of Chinese verse before me, I discovered that in the overwhelming majority of cases it was impossible to come up with an acceptable rhyming translation without sacrificing much of the content and almost all of the other formal elements of these poems. Too often it was the padding words that provided the rhymes, and too often the rhymes were lame. True enough, there were occasions where one might hit on a lucky rhyme, but they were very rare indeed.

The first collection of classical poetry of the Tang dynasty (618-906) that I published was Han Shan's 寒山 Poems of Cold Mountain (Gedichten van de koude berg, 1977). Han Shan's Buddhist verse may not enjoy high status in China, but his works have always remained popular in Japan, and in the 1950s and 196os, when Zen Buddhism attracted followers outside Japan 
in ever-increasing numbers, selections of his poems were translated into English (starting with Gary Snyder's renditions), French, and German. My interest in Han Shan had been aroused not so much by his poetry as by his reputation as a vernacular author, because I wanted to deepen my knowledge of the development of the vernacular language (白話). But once I started reading the poems with the aid of the excellent Japanese commentaries that were available, I could not help trying to render some of them into Dutch. And after I had succeeded in doing so once to at least my own satisfaction, I could not stop myself from doing more, until I had translated two hundred poems. I had the good fortune to be able to place this collection with a publisher, because the Cultural Revolution had raised considerable interest in China abroad - as well as heated debate - and De Arbeiderspers, which originated as the publisher of the socialist movement in the Netherlands, had set up a series of publications devoted to China past and present.

While working on Poems of Cold Mountain I became aware of a phenomenon that, I thought at the time, might well be peculiar to Dutch. ${ }^{2}$ When translating a five-syllable line and following the Chinese word order, many Dutch lines proved to be regular iambic lines of five feet. Now if the first line is a regular iambic line and the second is not, there is no problem. But if the second line also happens to be a regular iambic line, one has set up a pattern that creates the expectation in an experienced reader of Dutch poetry that he or she is reading blank verse, and that therefore the third line also will be an iambic line - if it is not, the reader will be unpleasantly surprised. From this I drew the conclusion that I had to make a choice: I either had to avoid regular iambics, or else to stick to iambic lines throughout. I chose the latter option. First of all, this saved me from the unwelcome tendency to extend the lines by inserting all kinds of explanatory materials. More importantly, it allowed me to suggest, if only faintly, something of the strict formal constraints under which China's traditional poets worked. Unlike many of their modern and contemporary counterparts, Chinese poets in premodern times did not write in free verse but adhered to strict formal rules, and a translation should preferably contain some reflection of that fact, even if it is impossible to replicate the rules in question in other languages. While an iambic line cannot reflect the tonal aspects of the

2 It is my impression that because of grammatical differences between English and Dutch, Dutch words often contain more unstressed syllables than English words, which makes for the easier generation of iambic lines. Conjugations and declensions in Dutch are often expressed by unstressed prefixes (such as ge-) and suffixes (such as - $e$ and -en). 
Chinese language at all, its consistent use throughout a poem, whether a quatrain (絕句) or a regulated poem (律詩), at least presents the reader with formal constraints, albeit not the exact same ones as in the original. For rhymeless but metrical translations I had a model in Dutch translations of classical Greek and Latin poetry (which did not rhyme in the original) and in the strictly metrical original Dutch verse which enjoyed a short vogue near the end of the eighteenth century.

Let me illustrate my approach with an example. One of Han Shan's poems is rendered by Robert C. Henricks as follows:

The thing to be pitied is this disease of living things; 憐底眾生病

They taste and they eat - but they generally never get full. 餐嚐略不厭

They steam the piglet - soaking it in garlic sauce;

Roast up the duck - add a dash of pepper and salt.

They take out the bones, making "raw slices of fish";

Leave the skin on, cook up the face meat.

They don't know the "bitterness" of other's [sic] lives;

Only hold on to the "sweetness" of their own homes. ${ }^{3}$
蒸豚搵赫醬
采鴨點椒鹽

去骨鮮魚膾 兼皮熟肉臉

不知他命苦 只取自家甜 $(1990,289)$

One may well wonder whether such a vegetarian tract is fit for poetry, and Henricks's version reads rather prosaic. Still, Han Shan left us his message in the shape of a perfect regulated poem, including the prescribed parallel couplets. In a poem like this it is neither the message nor the images that are original, but the witty versification. I turned Han Shan's poem into the following eight lines of metrical verse, also keeping as much as possible to the parallelism:

De kwaal der mensen waarmee 'k ben begaan?

Ze schransen, smullen onverzadigbaar!

Ze stoven big in knoflook en in soja,

Ze braden eend met peper en met zout.

3 In the second line, “They taste and they eat” translates 餐嚐, which more precisely should be rendered as "they dine and they taste." Han Shan's poem is not criticizing eating to still one's hunger, but the tendency to seek more and more exceptional flavors to please one's palate and kill living beings for that purpose. 
Ontdaan van graat - de rauwe visfilets;

Met huid en haar - de gare varkenswangen.

Ze laten rustig and're wezens lijden

Om zich de eigen tong te kunnen strelen.

(Idema 1977, 55, amended)

If poets "love to dance in fetters" (Perry 1920, 202, quoted in Wen 1996, 319), Han Shan may not exactly be doing grands jetés, but he is at least still wearing some shackles in this translation. I have never claimed that rhymeless metrical verse is the only way to render classical Chinese poetry. All I can say is that it worked for me, and I have stuck to it also in my later Dutch translations. ${ }^{4}$

Making this choice initially was made easier not only by the relatively low status of Han Shan, but also by the virtual absence of a tradition of Chinese poetry translation in the Netherlands. When I entered Leiden University, it had a tradition of teaching Chinese that stretched back for over a hundred years, but that tradition was rooted in the need of the administration of the Dutch East Indies for specialists in Chinese (later East Asian) affairs, and the teaching program was geared toward the future job situation of the students. ${ }^{5}$ For the first century of Dutch sinology, literature hardly featured in the teaching program. Translations of Chinese poetry directly from the Chinese had always been few and far between. "Chinese poetry" had enjoyed quite some popularity in the Netherlands in the 1920s and 1930s, but these "Chinese poems" (all metrical and rhymed) were free adaptations from the German Nachdichtungen (creative rewritings) by the German poets Hans Bethge (1876-1946) and Klabund (Alfred Henschke, 1890-1928), who had based their free adaptations on earlier French adaptations, for instance by Judith Gautier (1845-1917). ${ }^{6}$ The less authentic these poems were, the more popular they were with Dutch poets. The poem that was most often adapted by Dutch poets was Klabund's “The Tired Soldier” (Der müde Soldat), for

4 After moving to the United States in 1999, I also started to translate classical Chinese poetry, especially women's works, into English. Not being a native speaker of English, I initially did not try to produce metrical translations but followed the local preference for free verse. It is only in my recent Two Centuries of Manchu Women Poets (2017) that I did include a sizable number of metric renditions.

5 For a survey of Dutch studies in the Netherlands, see Idema 2014; for a detailed survey of China in Dutch literature, see Pos 2008.

6 Discussions of translations of poetry in English and Dutch are hampered by the absence of the German distinction between Nachdichtung and Übersetzung (translation that follows the source text, as distinct from creative rewriting). 
which no Chinese source can be identified. Here is the first stanza of the German poem, followed by my English translation:

Ein kahles Mädchen. Heckenblassentlaubt.

Sie steht am Weg. Ich gehe weit vorbei.

So stehen alle: Reih in Reih

Und Haupt an Haupt.

(Pos, Cheng, and Scheltens-Boerma 1993, 21)

A bald girl. A hedgerow wan without any leaves.

She stands by the side of the road. I pass her by.

So all of them stand there: row upon row,

And head upon head.

The best-known author of "Chinese poems" of this kind was the famous Dutch poet J. Slauerhoff (1898-1936), whose version turned the image completely around. This is Slauerhoff's rendition, followed by my translation into English:

Achter de hagen langs de straat

Staan zij in feestgewaad;

Geen schone kan mij nog wat schelen,

Zij mogen mijn soldij verdeelen!

(Pos, Cheng, and Scheltens-Boerma 1993, 21-23)

Behind the hedgerow by the side of the street

They stand in festive dress:

I don't give a damn about any beauty,

Let them divvy up my pay!

Most of Slauerhoff's adaptations were based on the English translations of Arthur Waley (1889-1966) (see Idema 2003). But Waley's renditions too were freely adapted by Slauerhoff, who turned the ambitious bureaucrat Bai Juyi 白居易 (772-846) into an alter ego of the alcoholic wanderer Li Bai 李白 (701-762), in whom Slauerhoff recognized much of himself. One example of this kind of rewriting is offered by Slauerhoff's adaptation of this translation by Waley of a poem by Bai Juyi:

“The poem on the wall” (駱口驛舊題詩)

Yüan Chên wrote that on his way to exile he had discovered a poem inscribed by Po Chü-i on the wall of the Lo-k'ou Inn 
My clumsy poem on the inn-wall none cared to see;

With bird-droppings and moss's growth the letters were blotched away. There came a guest with a heart so full, that though a page to the Throne, He did not grudge with his broidered coat to wipe off the dust, and read.

(Waley 1919, 46)

Slauerhoff's Dutch version reads as follows:

Ik heb een ruw gedicht op den herbergmuur gegrift.

Door vogelvuil en woek'rend mos half uitgewist.

Totdat een gast kwam: een die staat bij den Troon,

Hij veegde met zijn zijden mouw de steenen schoon

En las en weende, hij wist:

Po Tsju I is balling weer, verdreven door zijn drift.

(Pos, Cheng, and Scheltens-Boerma 1993, 86)

Slauerhoff's first four lines follow Waley's version quite closely, except that Slauerhoff's version rhymes. But the last two lines, which translate as "He read and wept: he knew / That Bai Juyi had been banished again, chased away by his own fury," are entirely of Slauerhoff's making.

Some Dutch poets of the Interbellum went so far as to produce volumes of "Chinese poems" of their own creation. When, several decades later, I started to produce my bare and unadorned direct translations of classical Chinese poetry, these would on occasion be criticized for their lack of Chinese flavor by Dutch critics. What they meant was, of course, that these translations disappointed them because of their lack of chinoiserie and of decadent romanticism in the manner of Slauerhoff.

By choosing to render Chinese poetry into metrical verse in my Dutch translations, I was going against the international trend at the time. Since the 1910s, when Arthur Waley started to publish his translations, English translators of Chinese verse had increasingly abandoned the use of rhyme and meter in their renditions. In my student days A. C. Graham (1919-1991) created quite a stir with the introduction of his Poems of the Late T'ang (1965), in which he stressed the primacy of the image in the translation of Chinese poetry. A few years later, in his article "A New Translation of a Chinese Poet: Li Ho" (1971), he repeated this argument, stressed the importance of maintaining the original word order, and blamed all the shortcomings he perceived in J. D. Frodsham's 1970 translation of the poems of Li He 李 賀 (790-816) on Frodsham's tendency to produce metrical versions. This emphasis on the image, laudable as it may be, has resulted in the relative 
neglect of almost all formal elements of classical Chinese poetry, and since then free verse - or lame prose, depending on the quality of the translator - has been by far the most popular vehicle for the translation of classical Chinese poetry in the Anglophone world.

\section{Purpose and difficulty}

Translators of Chinese poetry as a rule engage in their work because of their love of poetry, both in the source language and in the target language. Though haunted by Robert Frost's (in)famous dictum that "poetry is what gets lost in translation,"7 and only too aware of the impossibility of a perfect translation, they engage in the treasonous act of translation (as in the Italian "traduttore, traditore") because of the inherent pleasures it brings: finding the right word, phrasing a fitting sentence, and producing a version that at least to some extent approximates the original and reads well in the target language are a source of joy and gratification. Translators may of course stress the importance of their work in a global world (and rightly so), but I wonder how often that is their primary motivation. So far I have never encountered a translator of poetry whose primary motivation was financial. "Writing poetry brings me little profit" (Van dichten comt mi cleine bate), complained the unknown author of Beatrijs, a fourteenth-century Dutch legend in verse, and translating poetry is even less profitable. Poetry translators don't make good money at the expense of the poets they translate, whether dead or alive - as a rule, translators need other sources of income to make a living.

Still the purposes and audiences of their translations can vary a great deal, and this impacts the way one translates. In the words of Stephen Owen, "Translation is a craft that is contingent on its purpose, and the purpose is usually determined by the readers for whom it is intended" (2016, lxxxi). This is clearly demonstrated by the various English translations of the Book of Odes (Shijing 詩經; see Joseph Allen's essay in this volume). When the Hong Kong-based missionary James Legge (1815-1897) produced his translation of the Chinese Classics for the benefit of his fellow missionaries in China, he provided prose versions alongside the Chinese texts together with detailed annotations making ample use of Chinese characters. When the Swedish

7 Or, alternatively, "Poetry is that which is lost in translation." Both are misquotations of what Frost actually said: "I like to say, guardedly, that I could define poetry this way: it is that which is lost out of both prose and verse in translation" $(1959,7)$. 
sinologist and linguist Bernhard Karlgren (1889-1978) set out to reconstruct the original meaning of the Odes on the basis of the earliest preserved glosses, he too only provided rebarbative prose versions of these poems, for the enjoyment of his fellow philologists. When Legge produced a translation of the Book of Odes for a general audience back in Great Britain, being a good Victorian he produced a metrical, rhymed version, because contemporary readers expected poetry, whether in the original or translated, to be metrical and rhymed (as Legge often followed the metrical patterns of church hymns, his renditions of the poems in the Book of Odes are eminently singable, and as such a true Book of Songs). But when Arthur Waley published his English rendition of the Book of Odes, his translations were rhymeless, because by that time British and American poets were increasingly abandoning the use of rhyme. And while Waley tried to stay as close as possible to the source text, Ezra Pound (1885-1972) produced a highly idiosyncratic version that probably is best appreciated as an original creation. Much discussion of Pound's qualities as a translator could be considerably simplified if English, like German, could distinguish between Übersetzung 'translation' and Nachdichtung 'poetry composed after a source text'.

Since the 1950s, the United States have witnessed a third kind of audience for translations of classical Chinese poetry: the "captive audience" of undergraduate students who have signed up for classes in Chinese literature in translation. Such classes are rarely taught in European universities, where the lasting influence of their sinological tradition leads to an emphasis on reading texts in the original language, but they have been quite popular in the United States with its system of liberal education, allowing Departments of Chinese Language and Literature to reach out to a larger student body beyond those learning the language (initially only a very small number, in contrast to more recent decades). As these days the final destination of many translations for the general audience is that of prescribed reading for undergraduates (to the delight of our publishers), this is perhaps something many translators should take into account more consciously. After all, a typical freshman or sophomore can rarely be considered an experienced member of the general audience of poetry readers.

Some people like to stress the difficulty of classical Chinese poetry. But if one sees it as the translator's mission to translate the explicit message of the text in its own words and not necessarily its meaning, Chinese classical poetry is not all that difficult. Of course there are difficult poets and difficult poems, but they tend to be exceptions. But even in the case of notoriously difficult poems, such as "Brocade zither" (錦瑟) by Li Shangyin 李商隱 (813858 ), it is not the grammar or the allusions that trouble the translators, but 
the interpretation. Readers who are raised on classical Western poetry with its often highly rhetorical language and panoply of ancient gods and mythical characters are often positively struck by the simplicity and directness of Chinese classical poetry. Chinese classical poems tend to be short, and, as enjambment is rare if not non-existent in shi (詩) poems, lines are mostly end-stopped. Such lines of four, five, or seven syllables do not allow for the rhetorical contortions commonly found in classical Latin and Greek poetry, or Classicist poetry in the European vernaculars. It is not the fault of the ancient Chinese poets that speakers of Indo-European languages have to deal with conjugations and declensions, gender and number. The Chinese poets stick to the rules of their own grammar, and these are clear enough. When analyzing individual poems, Chinese critics then and now rarely feel a need to discuss individual lines in detail as regards grammar. Of course foreign readers may occasionally be baffled by the grammatical construction of individual lines (as they may by longer passages), but the more they read, the less that happens. Extensively annotated editions and numerous reference works are available to help them find their way through the minefields of rare expressions and obscure allusions. As younger Chinese know less and less of traditional Chinese culture, these annotations become more and more detailed. Translators may find themselves compelled to make choices to ensure grammatical usage in the target language, but that is a generic issue of translation, and not because Chinese poetry is "difficult" per se.

If Chinese poetry presents difficulties of understanding it is because it is the product of a different culture, but if the past is a foreign country, the Tang dynasty must be as alien to contemporary Chinese readers as to foreigners. The poetry of the past was written by different people, for different purposes, and for a different audience than Romantic and postRomantic poetry East and West, and as such it was written on different topics, used a different language, and employed other allusions than modern and contemporary poetry. I am afraid that this is what causes the greatest problems in translation. Many of us may agree that $\mathrm{Du} \mathrm{Fu}$ 杜甫 (712-770) is China's greatest poet, at least of the Tang dynasty. When introducing a selection of his poems to Western audiences, David Hawkes (1923-2009) commented as follows on his regulated poems $(1967,47)$ : "[Their] perfection of form lends [them] a classical grace which unfortunately cannot be communicated in translation. That is the reason why $\mathrm{Du} \mathrm{Fu}$, one of the great masters of the form, makes so comparatively poor a showing in foreign languages." When Stephen Owen (2016, lxxxi) modestly describes his fine translations of the complete works of $\mathrm{Du} F u$, the result of a lifetime of study and experience in translation and published in a bilingual edition, as only 
"a crib" for "those who have some level of Chinese, but whose Chinese is not up to reading Du Fu" (in the original, without assistance), that statement may well be informed by the same thought. But even more of an issue may be the fact that $\mathrm{Du} F u$ is also very much a Confucian poet, deeply frustrated by his inability to contribute to the ordering of the realm as an official in the imperial bureaucracy. And while it may be relatively easy to find the right words for the translations of his feelings of homesickness during his years of wandering, I found it very hard when working on a small Dutch anthology of Du Fu to find fitting expressions in my native language for the rendition of his repeatedly expressed fervent desire to serve the emperor and the realm (Idema 1989). That difficulty was further compounded by the fact that I wanted to avoid words with overly obvious Christian connotations in translating Du Fu's Confucian values and sentiments. ${ }^{8}$

Of course it is often difficult to ascertain the meaning of an individual poem, but then the search for single correct interpretations is doomed anyway. I also believe that the translator has a task in enabling the reader to explore the various possible meanings of the poems presented in translation. By the choices the translator unavoidably makes, he or she is already very much present in the translation, but to the extent possible he or she should not impose his or her own interpretation. Granted, because the translator often is the first to present the poet of his or her choice to a foreign audience, he or she also has to be a critic. But for that aspect of our activities, I believe, we have prefaces and introductions, postfaces and annotations.

8 “On the River" (江上; Owen 2016, vol. 4, 195-196), a regulated poem from Du Fu's years near the end of his life in Kuizhou, may serve as an example. After the first four lines have evoked the desolate autumn scenery of Kuizhou with its endless rain and barren trees, the poet continues with four lines that in a very literal rendition might read: "Merits and legacy? I often look in the mirror; / Service or retirement - Alone I lean on the tower['s balustrade/window.] / The times are perilous, I long to repay the lord: / Weakened and wilted I cannot let go (勳業頻看鏡 / 行 藏獨倚樓 / 時危思報主 / 衰謝不能休). The language is so simple that a modern, annotated edition of Du Fu does not provide any annotations for this poem (Wang Shijing 1999, 633). Now repay may be a fine translation of 報, but to me it smacks too much of a circumscribed financial transaction, and there is no way in which a person can ever fully repay the boundless grace of the Son of Heaven. Therefore, in my Dutch translation I opted for dienen 'to serve'. I would have liked to write "mijn Heer te dienen" (to serve my Lord) to bring out the nature of official service as the highest calling for a Confucian gentleman, but I toned my translation down to "mijn vorst te dienen" (to serve my king), which still shows Du Fu as a good patriot but makes the sentiment of the last couplet somewhat trite. The final Dutch translation reads: "Mijn daden? Dikwijls kijk ik in de spiegel. / De keuze - eenzaam leun ik uit het venster. / De lust om in de nood mijn vorst te dienen / Kan ik, ook oud en zwak, nog niet bedwingen" (Idema 1989, 118). When I reused this translation in a later publication $(1991,327)$, I changed "vorst" to "Vorst," with the uppercase $V$ suggesting that to $\mathrm{Du} \mathrm{Fu}$ the Chinese ruler may not be God, but is still the Son of Heaven. 
How much annotation one should provide will remain a topic of contention. By way of an example, in my opinion, the regulated poem by Han Shan which I introduced earlier can stand very well on its own and doesn't need much explanation. Chinese cuisine is nowadays sufficiently well known outside China that most readers will know that pork is its meat of choice, and Peking roast duck and its regional variants have established a worldwide reputation. The "minced fish" or "slices of fish" may be an allusion to the story of Xue Wei 薛偉, who as a lover of fish was turned into a fish in a dream, caught, and about to be served to his friends; and when he cried out to his friends for help when the chef prepared to slice him, they could see his mouth move but did not hear his pleas (see the story by Li Fuyan 李復 言 in Kao 1985, 266-270). But again, with the spreading popularity of sushi and sashimi, many non-Japanese have seen a Japanese chef wield his blade. In the following line, the expression "meaty cheeks" (肉臉) has perplexed interpreters, but I think the two characters mean exactly what they say. ${ }^{9}$ The use of "cheeks" is striking here because in poetry cheeks usually are the rosy cheeks of pretty girls, and not the pig cheeks prepared as a delicacy. But once one realizes the suggestion of the human in the word "cheeks," one may of course wonder whether the poet was already alluding to the kind of stories we know from later imperial times in which a convinced butcher abandons his trade on the spot when he realizes that the pig he is about to slaughter is his reincarnated parent (see Grant and Idema 2011, 124-135). And perhaps in the Dutch translation, "varkenswangen" will remind some readers of the frequent use of pigs in vivisection.

I must confess that I am not a fan of footnotes, even though I have not been able to avoid them completely. In my A Mirror of Classical Chinese Poetry from the Book of Odes to the Qing Dynasty (Spiegel van de klassieke Chinese poëzie van het Boek der Oden tot de Qing dynastie, 1991) I privilege poems that need little or no annotation, also because a translation that relies on annotation reads like a joke that has to be explained. One strategy I have applied from time to time is clarification through more translations. If I wanted to include a poem that made allusions to another poem, I would include that too, hoping the reader would catch the allusions by themselves. But this is tricky and increases the bulk, and the poem alluded to may not be a good poem at all. I also privilege longer poems which create their own atmosphere, suggesting an understanding of the images they contain. But whatever the translator will do, it will never be enough to recreate the original context of the poem, in which the poem functioned and was understood "by itself." 


\section{Rhyme and parallelism}

As long as the translator's aim is to provide cribs for reading the poem in its original language, he or she does not need to be overly concerned about the formal features of the works he or she translates. But if one aims for a general audience that is unable to read the originals, one has to take up the challenge of presenting the translations as poetry. Despite Graham's arguments of more than forty years ago, few classical Chinese poems can survive translation on the strength of their images alone. The fact of the matter is that only a few Chinese poets were as original as Li Shangyin and Li He in their use of imagery, and in their works too, these images further gain from the formal constraints of the poem. Li He and Li Shangyin belonged to generations that deliberately aimed for novelty or even strangeness (奇) in their diction, but in general the emphasis would appear rather to have been on the expression of the appropriate emotion. Much of classical Chinese poetry was social poetry, ruled by strict rules of decorum. Many fine poems achieve their quality not by the originality of their images, pace Graham, but by their skillful variation in the use of common imagery. As one commentator has remarked (I forget who and where), Chinese poets may be compared to jazz musicians as their poems all too often are variations on given themes.

Every translator has to choose which formal elements of the original poem to retain. In a way, the Victorian translators took the easy way out. For the sake of meter and rhyme in their own language they sacrificed almost all aspects of the original Chinese poem, except for an often vague correspondence in content. ${ }^{10}$ Arthur Waley, as mentioned before, broke with that practice: abandoning rhyme and adopting "sprung rhythm" he could often reproduce the word order of the original. Waley's sprung rhythm works out better for five-syllable lines than for seven-syllable lines; in my opinion, the latter are often indistinguishable from prose in his renditions. ${ }^{11} \mathrm{James} \mathrm{J}$. Y. Liu, who in his pioneering The Art of Chinese Poetry (1962) had included rhymed translations that faithfully followed the original rhyme patterns, later abandoned rhyme in his translations as he had come to realize "the virtual impossibility of keeping the rhymes without damage to the meaning" (quoted in Frankel 1984, 308). ${ }^{12}$ Following Graham's criticism of Frodsham's

\footnotetext{
10 Edward H. Schafer, otherwise known as a quite barbarizing translator of Chinese poetry, once provided multiple translations of a single Chinese poem in different period styles of English poetry (1963).

11 For a recent discussion of Arthur Waley as a translator, see Raft 2012.

12 The most successful examples of rhymed translations of Chinese poems from the second half of the twentieth century may well be David Hawkes's renditions of the poems in his translation
} 
translation of Li He, many translators have since abandoned any attempt to maintain a metrical equivalence between the lines in the Chinese poem and in their translation. ${ }^{13}$

Chinese readers of English translations of Chinese classical poetry are often disappointed by the lack of rhyme in these translations, and in recent decades several Chinese translators of classical Chinese poetry have produced rhyming translations. Unavoidably, they run into the same issues as foreign translators of classical Chinese poetry, having to sacrifice almost every other formal element for the sake of rhyme, and often to adapt the content to the available rhymes. The diction in such translations is often trite. Nor do they always seem to be aware that in English, rhyme works in conjunction with meter and rhyme without meter easily results in doggerel. I find their insistence on the use of rhyme puzzling. True enough, all genres of classical Chinese poetry rhyme in one way or another, but so do some genres that are classified as "prose" in China, for instance the "rhapsody" (賦). So rhyme cannot be counted as a distinctive characteristic of poetry in China. Moreover, if the sound of the rhyme were so important to Chinese readers, one would expect them to read poetry in the pronunciation of the time of its composition, but that is not the case. Since the Tang dynasty, the “entering tone" (入聲) has disappeared from the standard language, and many words have changed their tone and sound. Even during the Tang, rhyme categories were to a certain degree artificial constructs. Some dialects claim relative proximity to Tang-era pronunciation, and some maintain at least most of the tonal distinctions of that period, but no one proposes to make these dialects the standard for reading and reciting Tang poetry. Last but not least, traditional Chinese critics rarely if ever discuss the use of rhyme of the poems they analyze - apparently, its formal perfection is taken for granted.

These critics can assume formal perfection because rhyming is relatively easy in Chinese. The number of rhyme sounds is limited, and many rhyme categories are "broad," containing hundreds of words. Even the so-called "narrow" rhyming categories contain dozens of words. Because rhyming is easy, there rarely is a special emphasis on the rhyming word. The most important word in a line of verse rarely is the rhyming word; the "eye" (眼) of a verse is usually found elsewhere in the line. Chinese poets can maintain, if

of the first eighty chapters of the eighteenth-century Story of the Stone (石頭記 or 紅樓夢) by Cao Xueqin 曹雪芹. See Hawkes and Minford 1973-1986.

13 Attempts to translate classical Chinese poetry in lines of the same number of syllables as in the original have been few and far from successful. 
they wish, the same rhyme for dozens and scores of lines, and occasionally one comes across poems in which the poet uses as many as possible of the words from a given rhyme category without a single repetition. In Germanic languages, however, many rhyme sounds have a limited number of rhyming words, so using a specific word in rhyming position usually creates strong expectations about the possible rhymes in the subsequent lines. Multiply repeated rhyme is often experienced as contrived and boring, precisely because rhyming is much more "present" in poetry in Germanic languages than in Chinese poetry. Most translators who use rhyme in their English renditions of classical Chinese poetry silently acknowledge the limitations of rhyme in that language: even when rhyming they rarely make an effort to reproduce the rhyming patterns of the source language.

Whereas traditional Chinese critics devote little attention to rhyme, they are fascinated by the well-crafted couplet. Of course they also discuss individual lines, but it would seem that the parallel couplet is even more important in their eyes. This fascination with the parallel couplet is of course not limited to poetry: parallelism is encountered in all genres of Chinese writing, and has even engendered its own genre as free-standing couplets (對聯). Couplets are encountered as inscriptions on buildings and are displayed at all manner of events, and in traditional education students were trained from early on in the composition of increasingly complex parallel lines. Whereas in the West one finds stories about words for which no one has ever come up with a fitting rhyme word (until someone finally does), there are many anecdotes in China about difficult lines for which no one had ever been able to come up with a matching line (until a child prodigy does). The characteristics of classical Chinese greatly facilitate the composition of parallel couplets, which has doubtless enhanced their popularity, but I believe that the composition of parallel lines is more than an erudite skill and playful competition. In traditional Chinese cosmology the world is made up of contrasting and competing but also synergetic forces and elements, and just as abstract concepts are often created by naming two representative but different members of a group, the author of a couplet tries to grasp the totality of a scene or an emotion by contrasting its most conspicuous elements. In parallel couplets it is not the single image that counts, but the paired image. One of the most important genres of classical Chinese poetry since the Tang has been the eight-line "regulated poem," of which the two inner couplets have to be parallel. Yet the majority of translators of classical Chinese poetry East and West have treated parallel couplets in a cavalier fashion - and indeed often deliberately broken up the parallelism. Hans Frankel, otherwise a 
sensitive reader of classical Chinese poetry, commented as follows in his survey of the ways in which translators had dealt with the formal features of classical Chinese poetry:

Parallelism and antithesis are significant features in classical Chinese poetry, and they are occasionally employed in English poetry. But a long series of end-stopped lines and too much precise parallelism tends to sound bad in English. Therefore some of the best translators deliberately break up the parallelism of Chinese couplets.

$(1984,318)$

Even the translators who are said by Frankel to "skillfully preserve syntactic and semantic parallelism" rarely achieve the precision of their source texts. In Graham's discussion of the problems in translating Tang-dynasty verse one may observe the same reserve towards the parallel couplet: "It is clear that in English strict parallelism without repeating a word is nearly impossible, while parallelism involving repetition will quickly seem rigid and monotonous" $(1965,27)$.

Let's have one more look at the poem by Han Shan we discussed earlier. Let me first refresh your memory by quoting two more English translations by experienced translators. Red Pine offers the following rendition:

The unfortunate human disorder

a palate that never wearies

of steamed baby pig in garlic

of roast duck with pepper and salt

of deboned raw fish mince

of unskinned fried pork cheek

unaware of the bitterness of others' lives

as long as their own are sweet.

$(2000,173)$

And Paul Rouzer translates:

A pity, this sickness in human beings:

In eating, nearly insatiable.

Steamed piglets, soaked in garlic sauce,

Roast duck with salted peppers,

Fresh minced fish, their bones removed,

Broth of meat simmered with its skin. 
They don't know the sufferings of other living things,

Only choose the sweetness for themselves.

$(2016,220-221)$

As a regulated poem, its second and third couplet consist of parallel lines. But the rules for regulated poems don't stop there. Whereas the tonal contrasts inside the third couplet should replicate the tonal contrasts of the second, ${ }^{14}$ the grammar of 11.5 -6 should not replicate that of $11.3-4$. As a quite conventional poet in formal matters, Han Shan's ll. 3-4 each consist of two verbal phrases, whereas 11.5 -6 consist, in my reading, of nominal phrases with strongly emphasized caesuras following the second syllable. None of the three English translations quoted above attempts to reproduce the parallelism within the couplets, and none highlights the different grammatical structure of the second couplet and the third. Henricks comes close, but in the second couplet "garlic sauce" is matched by "pepper and salt." If a given position in the second line of a couplet has two things, the corresponding position of the first line should presumably also have two, and I suppose the poet intended "garlic and soy sauce" as the relevant cooking ingredients. ${ }^{15}$ Rouzer's "garlic sauce" is at least paralleled by "salted peppers" (which may be questionable as a translation), but whereas he has his piglets "soaked" in garlic sauce, no verb precedes his "salted peppers." Red Pine simply omits the sauce. Perhaps even more remarkable is that both Red Pine and Rouzer turn 1l. 3-6 into nominal phrases, deemphasizing the difference in grammatical structure between the second and third couplets.

That the internal couplets of a regulated poem have a paratactic structure does not mean there is no logical progression. In Han Shan's poem we move from a pig prepared with homegrown condiments to a duck prepared with spices and expensive salt. The removal of bones may suggest the extreme care with which the fish is prepared but the same line may hint at the fear of being eaten oneself. If the skin is left on, ${ }^{16}$ the diners are no better than wild

14 The rules for tonal contrast in new-style poetry (近體詩) were developed and perfected over the course of the fifth and sixth centuries, once the Chinese had become aware of the tonal nature of their own language through contrast with the prosody and chanting practices of Sanskrit and Prakrit, where prosody is based on the patterning of long and short vowels. See Mair and Mei 1991. 15 The dishes are not prepared in the simplest manner with only one spice but with several, in order to appeal to the demanding taste of gluttons.

16 In the spirit of the nitpicking I am engaging in here, I should also criticize my own rendition of 兼皮 as “met huid en haar" 'with hide and hair', which adds bristles to the skin and is not perfectly parallel to "ontdaan van graat" 'with bones removed'. I simply could not resist the temptation of this set phrase in Dutch. To achieve better parallelism, "nog met het vel" 'still with the skin' would have been preferable. 
animals devouring their prey - they may well be cannibals devouring their parents. The final couplet presents the conclusion; while it may have the form of a parallel couplet, the two lines often have a hypotactic structure. It is somewhat surprising that the three English translators stick to parataxis, presumably in an effort to bring out the contrast between the final words of the lines, "bitter/bitterness/suffering" (苦) and “sweet/sweetness/pleasant" (甜). But once one renders 苦 here idiomatically as "sufferings," as Rouzer does, one may of course also choose a more idiomatic rendering of the last line. Henricks's "sweetness of their own homes" goes off in the wrong direction because of a misunderstanding of the vernacular expression "self, oneself" (自家). Red Pine and Rouzer's translations seem to hint at a generally pleasant existence, losing the link to food. The final couplet of my Dutch version would translate into English as "They happily have other beings suffer / in order to please only their own palate."

The reluctance to do full justice to the frequent use of parallelism in Chinese classical poetry on the part of many translators is usually defended with an appeal to the characteristics of Germanic languages like English and the limited occurrence of precise parallelism in Western literature. More often, I fear, the sloppy treatment of parallelism in translation stems from a prejudice on the part of modern readers against parallelism as outmoded wordplay. But if the parallel couplet is such an essential aspect of Chinese poetry, translators have to try harder. Bai Juyi may be known for the deliberate simplicity of his style, but he also wrote a number of long regulated poems (排律) in which he displayed his magisterial virtuosity in crafting parallel couplets, and when working on my Dutch anthology of his works (2001), I felt a duty to include some of these poems in order to display the variety of his poetry. I can only say that I personally derived great pleasure from turning these poems into Dutch as precisely as possible, and I hope that some of my readers will have enjoyed seeing the author vary his syntactical patterns from couplet to couplet. Form matters, and if some aspects are impossible to reproduce in translation and others only at great cost, that is all the more reason to care especially about those aspects that it is actually possible to retain or represent.

\section{Skills and talent}

Literary translation as a craft requires numerous skills. The first of these is a sound knowledge of the source language and of the culture in which the author of the original flourished. This also implies extensive knowledge 
of the various editions of the poet's works and other relevant reference works. Secondly, literary translation requires true mastery of the target language, which results in the rule of thumb that translations are most likely to succeed when done by a native speaker. Thirdly, and most importantly, it requires the willingness to use these skills in the service of the poetry to be translated. Few translators fully combine these three qualities in their person. I certainly don't. And as if these three requirements were not enough, on top of all this literary translation also requires talent. Nor do skills plus talent guarantee that a translation will be successful and find a ready audience. For the committed translator of poetry, however, that disappointment pales alongside the frustration at the inability to find the perfect word.

\section{Works cited}

Frankel, Hans H. 1984. "English Translations of Classical Chinese Poetry Since the 1950s: Problems and Achievements." Tamkang Review 15: 307-328.

Frodsham, J. D., trans. 1970. The Poems of Li Ho (791-817). The Oxford Library of East Asian Literatures. Oxford: Clarendon Press.

Frost, Robert. 1959. Conversations on the Craft of Poetry, edited by Cleanth Brooks and Robert Penn Warren. New York: Holt, Rinehart and Winston.

Graham, A. C. 1965. Poems of the Late T'ang. London: Penguin.

- 1971. “A New Translation of a Chinese Poet: Li Ho 李賀.” Bulletin of the School of Oriental and African Studies, University of London 34 (3): 560-570.

Grant, Beata, and Wilt L. Idema, trans. 2011. Escape from Blood Pond Hell: The Tales of Mulian and Woman Huang. Seattle: University of Washington Press.

Hawkes, David. 1967. A Little Primer of Tu Fu. Oxford: Clarendon Press.

Hawkes, David, and John Minford, trans. 1973-1986. The Story of the Stone. London: Penguin.

Henricks, Robert G., ed. and trans. 1990. Han Shan 寒山. The Poetry of Han-Shan: A Complete, Annotated Translation of Cold Mountain. Albany: SUNY Press.

Idema, Wilt L., ed. and trans. 1977. Han Shan 寒山. Gedichten van de Koude Berg [Poems of Cold Mountain]. Amsterdam: De Arbeiderspers.

一, ed. and trans. 1989. Du Fu 杜甫. Deverweesde boot: klassieke Chinese gedichten [The orphaned boat: classical Chinese poetry]. Amsterdam: Meulenhoff.

—, ed. 1991. Spiegel van de klassieke Chinese poëzie van het Boek der Oden tot de Qing dynastie [Mirror of classical Chinese poetry from the Book of Odes to the Qing dynasty]. Amsterdam: Meulenhoff.

一, ed. and trans. 2001. Bai Juyi 白居易. Gedichten en proza [Poems and Prose]. Amsterdam: Atlas. 
-. 2003. "Dutch Translations of Classical Chinese Literature: Against a Tradition of Retranslation." In One into Many: Translation and the Dissemination of Classical Chinese Literature, edited by Tak-hung Leo Chan, 213-242. Approaches to Translation Studies 18. Amsterdam: Rodopi.

—, ed. 2014. Chinese Studies in the Netherlands: Past, Present and Future. Leiden: Brill.

—, ed. and trans. 2017. Two Centuries of Manchu Women Poets: An Anthology. Seattle: University of Washington Press.

Kao, Karl S. Y. 1985. Classical Chinese Tales of the Supernatural and the Fantastic: Selections from the Third to the Tenth Century. Chinese Literature in Translation. Bloomington: Indiana University Press.

Liu, James J. Y. 1962. The Art of Chinese Poetry. Chicago: The University of Chicago Press.

Mair, Victor and Tsu-Lin Mei. 1991. "The Sanskrit Origins of Recent Style Prosody.” Harvard Journal of Asiatic Studies $5^{1}$ (2): 375-470.

Owen, Stephen, trans. 2016. The Poetry of Du Fu. Berlin: De Gruyter.

Perry, Bliss. 1920. A Study of Poetry. Boston: Houghton Mifflin.

Pos, Arie. 2008. "Het Paviljoen van Porselein: Nederlandse Literaire Chinoiserie en het Westerse Beeld van China (1250-2007)" [The Porcelain Pavilion: Dutch literary chinoiserie and the Western image of China (1250-2007)]. PhD dissertation, Leiden University.

Pos, Arie, Shaogang Cheng, and Nanneke Scheltens-Boerma, eds. 1993. Dronken in de Lente: De Chinese gedichten van J. Slauerhoff [Drunk in spring: the Chinese poetry of J. Slauerhoff]. Leiden: Barabinsk.

Raft, Zeb. 2012. "The Limits of Translation: Method in Arthur Waley's Translations of Chinese Poetry." Asia Major 25 (2): 79-128.

Red Pine (Bill Porter), trans. 20oo. Han Shan 寒山. The Collected Songs of Cold Mountain. Port Townsend: Copper Canyon Press.

Rouzer, Paul F., trans. 2016. Han Shan 寒山. The Poetry ofHanshan (Cold Mountain), Shide, and Fenggan. Berlin: De Gruyter.

Schafer, Edward H. 1963. "Mineral Imagery in the Paradise Poems of Kuan-Hsiu." Asia Major 10: 73-102.

Waley, Arthur, trans. 1919. More Translations from the Chinese. New York: Knopf. Wang Shijing 王士菁. 1999. 《杜诗今注》 [Du Fu's poetry annotated for the present day]. Chengdu: Ba Shu shushe.

Wen Yiduo 聞一多. 1996. "Form in Poetry." In Modern Chinese Literary Thought: Writings on Literature, 1893-1945, edited by Kirk Denton, translated by Randy Trumbull, 318-327. Stanford: Stanford University Press. 


\section{About the author}

Wilt L. IDEMA studied sinology in Leiden, Sapporo, Kyoto, and Hong Kong, and taught at Leiden University from 1970 to 1999 and at Harvard University from 2000 to 2013 . He has published widely on vernacular traditions in Chinese literature of the period 900-19oo and late-imperial Chinese women's poetry. For his Dutch translations of classical Chinese poetry, especially his 1991 Mirror of Classical Chinese Poetry from the Book of Odes to the Qing Dynasty (Spiegel van de Klassieke Chinese poëzie van het Boek der Oden tot de Qing-dynastie [Meulenhoff]), he received the 1992 Martinus Nijhoff Award. His recent publications include Two Centuries of Manchu Women Poets: An Anthology (University of Washington Press, 2017), Mouse vs. Cat in Chinese Literature: Tales and Commentary (University of Washington Press, 2019), and Insects in Chinese Literature: A Study and Anthology (Cambria Press, 2019). 
